\title{
Upaya Peningkatan Hasil Belajar Siswa pada Mata Pelajaran PKn melalui Model Pembelajaran Berbasis Portofolio
}

\section{Ni Wayan Teni*}

\author{
SD No. 3 Pelaga
}

\section{A R T I C L E I N F O \\ Article history: \\ Received 19 November 2018 \\ Received in revised form \\ 30 December 2018 \\ Accepted 10 January 2019 \\ Available online 23 \\ February 2019}

Kata Kunci:

hasil belajar PKn, Model

Pembelajaran Berbasis

Portofolio

Keywords:

Civics learning outcomes, Portfolio Based Learning Model

\begin{abstract}
A B S T R A K
Penelitian ini bertujuan untuk meningkatkan hasil belajar siswa melalui penerapan Model Pembelajaran Berbasis Portofolio pada mata pelajaran PKn dikelas IV SD No. 3 Pelaga. Jenis metode penelitian menggunakan metode penelitian tindakan kelas dengan alur putaran spiral Kemmis dan Taggart. Subjek penelitian adalah siswa kelas IV SD No. 3 Pelaga yang berjumlah 22 siswa. Teknik pengumpulan data menggunakan tes dan observasi. Validitas instrumen dengan menggunakan expert judgement (pendapat ahli). Teknik analisis data menggunakan analisis deskriptif kualitatif dan kuantitatif. Indikator keberhasilan penelitian ini ditandai dengan meningkatnya hasil belajar PKn, untuk ranah kognitif mencapai Kriteria Ketuntasan Minimal (KKM), untuk ranah afektif dan psikomotorik telah mencapai kriteria baik. Hasil penelitian menunjukkan bahwa dengan proses belajar mengajar dengan menerapkan Model Pembelajaran Berbasis Portofolio dapat meningkatkan hasil belajar PKn. Ini dibuktikan dengan meningkatnya rata-rata nilai siswa dari 73,64 menjadi 82,27 pada siklus 2 .
\end{abstract}

\section{A B S T R A C T}

This study aims to improve student learning outcomes through the application of a Portfolio Based Learning Model on Civics subjects in class IV SD No. 3 Pelaga. This type of research method uses classroom action research methods with spiral round grooves Kemmis and Taggart. The research subjects were fourth grade students of SD No. 3 Pelaga totaling 22 students. Data collection techniques use tests and observations. Instrument validity using expert judgment. Data analysis techniques used qualitative and quantitative descriptive analysis. The indicator of the success of this study is marked by the increase in PKn learning outcomes, for the cognitive domain to reach the Minimum Completion Criteria, for the affective and psychomotor domains have reached good criteria. The results of the study show that the teaching and learning process by applying the Portfolio Based Learning Model can improve PKn learning outcomes. This is evidenced by the increase in the average value of students from 73.64 to 82.27 in cycle 2. 


\section{Pendahuluan}

Tujuan umum dari PKn pada dasarnya adalah bagaimana menjadikan warganegara yang baik yang mampu mendukung bangsa dan negara. Menjadi warganegara yang baik dapat dipupuk dari lingkungan keluarga, sekolah, maupun lingkungan masyarakat. Salah satu cara untuk membentuk siswa menjadi warganegara yang baik dari lingkungan sekolah adalah dengan memberikan pembelajaran PKn dengan benar. Mengutip pendapat Lipset (dalam Malian dan Marzuki, 2003: vii), mata pelajaran PKn merupakan pelajaran yangmenitikberatkan pada pembentukan karakter dan kesadaran pribadi pada setiapwarga negeranya agar mampu melaksanakan hak-hak dan kewajibannya sebagaiwarga negara. Warga negara diharapkan menjadi insan yang mampu menempatkan segala sesuatu pada tempatnya, mengutamakan kepentingan umum di atas kepentingan pribadi, mau dan mampu bertoleransi dengan sesama, serta diharapkan memiliki jiwa demokratis. Tentunya, tujuan ini akan tercapai jika PKn diberikan dan diajarkan dengan cara yang tepat. Sebagaimana tertuang dalam Pasal 37 Undang-undang Nomor 20 Tahun 2003 tentang Sistem Pendidikan Nasional, Pendidikan Kewarganegaraanmerupakan pendidikan yang wajib diberikan di semua jenjang pendidikan. Dalamhal ini tentunya jenjang pendidikan dasar mendapat perhatian lebih dikarenakan jenjang pendidikan dasar mempunyai peranan yang sangat vital. Jenjang pendidikan dasar merupakan pondasi yang sangat menentukan dalam membentuksiswa menjadi warga masyarakat yang baik. Ditegaskan pula dalam UU RI No. 20 tahun 2003 tentang Sistem Pendidikan Nasional (2003: 25, 66) pasal 37 (1), bahwa dalam kurikulum pendidikan dasar dan menengah wajib memuatpendidikan agama, pendidikan kewarganegaraaan, bahasa, matematika, ilmupengetahuan alam, ilmu pengetahuan sosial, seni dan budaya, pendidikan jasmanidan olahraga, keterampilan/kejuruan, dan muatan lokal.

Meninjau dari tujuan umum pelajaran PKn di atas, jelas bahwa dalam pembelajaran PKn tidak sekedar menitikberatkan pada aspek kognitif akan tetapi aspek lainnya seperti sikap atau tingkah laku dan keterampilan dengan harapandapat membentuk warga negara yang baik. Ironisnya, pelaksanaan pembelajaran PKn di Indonesia banyak menganut paradigma lama mengenai prosespembelajaran yang bersumber pada guru (teachercenter) bahwa pikiran seorangsiswa adalah seperti kertas kosong yang putih bersih dan siap menunggu coretan-coretan dari gurunya. Jadi dalam teori ini siswa cenderung pasif atau lebih tepatdikatakan bahwa pembelajaran terpusat pada guru dengan metode ceramah danmengharapkan siswa D3CH (Duduk, Diam, Dengar, Catat, dan Hafal). Sehubungan dengan hal itu, pembelajaran yang banyak melibatkan unsur yangsaling berhubungan seperti guru, siswa, sarana, dan prasarana, dan lain-laindiharapkan mampu menciptakan suatu sistem pembelajaran yang berkualitas,dimana siswa dituntut secara aktif dalam pembelajaran. Untuk mencapai haltersebut maka diperlukan adanya strategi yang tepat dalam mencapai tujuanbelajar yang diharapkan (Anita Lie, 1997: 23). Pencapaian kondisi pembelajaran yang berkualitas dan efektif. Menurut Usman (1989: 21-33) dalam bukunya Menjadi Guru Profesional, setidaknya ada yang menentukan keberhasilan belajar siswa, yaitu sebagai berikut:

1) melibatkan siswa aktif, 2) menarik minat dan perhatian siswa, 3) membangkitkan motivasi siswa, 4) prinsip individualitas, 5) peragaan dalam pengajaran. Profesionalisme seorang guru sangatlah dibutuhkan guna terciptanya suasana proses pembelajaran yang efektif dan efisien dalam pengembangan siswayang memiliki kemapuan beragam. Guru sebagai fasilisator dalam pendidikanharus mampu mefasilitasi siswa untuk mengembangkan kemampuannya yang beragam. Maksudnya tidak hanya memperhatikan hasil akhir tetapi juga harusmemperhatikan proses pembelajaran di kelas. Selain itu guru juga harus dapatmenggunakan metode, media, maupun model pembelajaran yang tepat sebagaiupaya meningkatkan kualitas pendidikan. Pemilihan berbagai metode, media, maupun model pembelajaran yangbanyak jenisnya tentu harus dipertimbangkan sebelum digunakan, misalnyadengan memperhatikan beberapa aspek seperti materi yang akan disampaikan,tujuan pembelajaran, waktu yang tersedia serta hal-hal yang berkaitan dengan proses pembelajaran.

Salah satu tantangan mendasar dalam pelajaran PKn dewasa ini adalah mencari model pembelajaran inovatif yang memungkinkan bagipeningkatan mutu Pendidikan Kewarganegaraan. Dalam mata pelajaran PKn diperlukan model pembelajaran yang mampu mengakomodasi siswa dalam mengembangkan potensinya masing-masing sebagai manusia demokratis. Model pembelajaran yang tidak sekedar menitikberatkan pada aspek kognitif akan tetapi aspek lainnya seperti sikap atau tingkah laku dan keterampilan dengan harapandapat membentuk warga negara yang baik, yang demokratis. Proses pembelajara PKn yang masih menggunakan model pembelajaran konvensional, siswa cenderung pasif atau lebih tepat dikatakan bahwa pembelajaran terpusat pada guru dengan metode ceramah. Pembelajara semacamini belum mampu mengembangkan aspek sikap dan keterampilan siswa dalamproses pembelajaran. Sebagian guru SD mengalami kesulitan dalam mengembangkan model pembelajaran yang tepat untuk suatu mata pelajaran, dikarena untuk sekolah tingkat dasar ini menganut sistem guru kelas 
sedangkan guru dituntut untukmengejar target materi yang cukup banyak dan harus diselesaikan pada tiapsemester. Seperti misalnya pada mata pelajaran PKn, guru perlu mengembangkan banyak sumber belajar, metode, model pembelajaran maupun media.

Kondisi pembelajaran di atas juga dialami di kelas IV SD No 3 Pelaga yang terletak di Desa Pelaga, Kecamatan Petang, KabupatenBadung, Propinsi Bali. Hasil belajar siswa SD No 3 Pelagaini masih kurang. Hasil observasi yang ada, ketika siswa dihadapkanpada suatu materi pelajaran abstrak, siswa sangat kesulitan untuk menangkap informasi dan memahaminya. Hal ini dikarenakan siswa kelas IV merupakansiswa yang sedang mengalami perubahan cara berpikir praoperasional keoperasional konkrit. Siswa belum mampu secara penuh menangkap informasiyang bersifat abstrak. Pada pelaksanaan pembelajaran PKn, siswa cenderung pasif, banyak mendengarkan materi yang disampaikan guru tanpa adanya timbal balik, belum diterapkan pembelajaran yang mengangkat nilai-nilai demokratis. Tak jarang banyak ditemukan siswa membuat gaduh, tidak memperhatikan penjelasan guru karena siswa merasa sulit memahami materi, terlebih tidak adanya daya tarik dalam penyampaian materi. Guru menggunakan model pembelajaran yang monoton. Guru menyampaikan materi, kemudian siswa latihan mengerjakan soal.Penyampaian materi oleh guru kurang jelas.

Dari segi perhatian siswa sendiri masih kurang fokus ketika pembelajaran berlangsung. Lingkungan SD berada satu lokal dengan TK. Hal ini kadang membuat suasana menjadi lebih ramai. Siswasering memperhatikan lingkungan di luar kelas, sehingga materi yang telahditerima juga tidak sepenuhnya dapat mereka serap dengan baik. Akhirnya semuaini, menyebabkan pencapaian hasil belajar siswa yang meliputi kognitif, afektif,dan psikomotorik kurang dari Kriteria Ketuntasan Minimal (KKM) yang telah ditentukan. Model pembelajaran yang mampu menampung tujuan mata pelajaran PKn dan kemudian untuk diaplikasikan dalam kehidupan nyata yaitu Model Pembelajaran Berbasis Portofolio (MPBP). Seperti yang di ungkapkan Boediono (dalam Budimansyah, 2002: 3), Model pembelajaran Berbasis Portofolio merupakan satu bentuk dari praktik belajar kewarganegaraan, yaitu suatu bentuk inovasi dalam pembelajaran yang dirancang untuk membantu siswa memahami teori secara mendalam melalui pengalaman belajar praktik-empirik. Guru dapat menggunakan portofolio sebagai model pembelajaran. Portofolio dapat melengkapi model pembelajaran konvensional yang selama ini digunakan oleh banyak guru (Ulum, 2018). Portofolio merupakan bukti yang tidak hanya menunjukkan hasil belajar tetapi juga upaya yang telahdilakukan siswa dalam mencapai belajar, proses yang telah dilalui siswa sertakemajuan yang diperoleh dari upaya dan proses yang dijalani dari hari ke hari. Portofolio adalah semua benda yang berbentuk bukti fisik sebagai sesuatu yang menunjukkan hasil kinerja peserta didik (Darmayanti, 2018). Portofolio dapat berbentuk kertas ulangan harian, kertas ulangan semesteran, buku pekerjaan rumah,sebagai bukti kinerja siswa (Sulastri, 2018). Pengajaran yang berfokus pada portofolio memberikan keuntungan.Salah satu keuntungan menggunakan portofolio dalam pembelajaran yaitu siswa dapat menggambarkan pembelajaran mereka sendiri dan cara-cara memperbaikinya (Fauzia, 2018).

Dari salah satu pengertian portofolio tersebut, dapat diketahui bahwa portofolio merupakan model pembelajaran yang mampu mengakomodasi beragam potensisiswa yang muncul dalam proses pembelajaran, terutama proses pembelajaran PKn.

Berdasarkan berbagai alasan tersebut di atas, penulis ingin memecahkan masalah hasil belajar siswa yang muncul di SD No 3 Pelaga melalui Model Pembelajaran Berbasis Portofolio (MPBP), karena model pembelajaran tersebut merupakan satu bentuk dari praktik pembelajaran PKn. MPBP merupakan model pembelajaran yang dalam penerapannya memuat nilai-nilai demokratis, mampu mengembangkan ketiga aspek kemampuan siswa (kognitif, afektif, danp sikomotorik). MPBP juga merupakan model pembelajaran yang menyenangkan serta membutuhkan indera ganda yang tentunya itu akan memberikan keuntungan bagi siswa seperti dengan teori yang disampaikan di atas.

\section{Metode}

Penelitian yang akan dilaksanakan ini dikategorikan ke dalam Penelitian Tindakan Kelas (PTK). Suhardjono (2007: 58) mendefinisikan Penelitian Tindakan Kelas adalah penelitian tindakan (action research) yang dilakukandengan tujuan untuk memperbaiki mutu pelaksanaan pembelajarannya di kelas.Dalam literatur bahasa Inggris, PTK ini disebut dengan Classroom Action Research. Secara umum PTK ini dapat dimanfaatkan oleh guru untuk perbaikan.Perbaikan disini mempunyai maksud bahwa melalui PTK guru dapat mengadaptasi teori yang ada untuk kepentingan proses dan atau produk pembelajaran yang mempunyai efektivitas tinggi, optimal, dan fungsional (Suyanto, 1996: 3). Bentuk penelitian tindakan kelas yang dipakai adalah penelitian kolaboratif. Disini penelitian melibatkan beberapa pihak baik guru sebagai observer, kepala sekolah SD No. 3 Pelaga, maupun guru lain serta masyarakat sekitar secara serentak dengan tujuan untuk meningkatkan pelaksanaan pembelajaran, 
menyumbang pada perkembangan teori, dan peningkatan karier guru. Hubungan diantara beberapa pihak tersebut bersifat kemitraan. Peran antara peneliti dan guru adalah sejajar. Artinya guru berperan sebagai peneliti selama penelitian tindakan kelas yang bersifat kolaboratif itu berlangsung.

Subjek penelitian adalah siswa kelas IV SD No. 3 Pelaga. Jumlah siswa di kelas ini sebanyak 22 siswa dengan perincian siswa laki-laki 16 dan 6 siswa perempuan. Penelitian ini dilaksanakan pada pertengahan semester II tahun ajaran 2016/2017. Penelitian dilaksanakan dari bulan Januari 2016 sampai dengan Juni2016. Adapun tempat penelitian adalah di SD No. 3 Pelaga.

Kegiatan pada masing-masing siklus mempunyai empat komponen yaitutahap perencanaan (plan), pelaksanaan (action), observasi (observation), danrefleksi (reflection). Siklus II dan siklus III dilaksanakan apabila tahap-tahap pada siklus I tidak terlaksana dengan baik serta hasilnya belum maksimal.Tahaptahap yang akan dilaksanakan pada siklus I sesuai FX. Soedarsono (1996: 16) dalam Pedoman Pelaksanaan Penelitian Tindakan Kelas, dijelaskansebagai berikut:

1. Tahap perencanaan (plan) Meliputi rencana tindakan apa yang akan dilakukan untukmemperbaiki, meningkatkan, atau merubah perilaku dan sikap sebagai solusi.Adapun kegiatannya yaitu : (a) Menetapkan subyek penelitian yaitu siswa kelas III, dan tempatpembelajaran untuk mempermudah memperoleh data, (b) Mengidentifikasi masalah kemudian mengambil masalah yang paling esensial. Di dalam PTK ini masalah yang diambil adalah hasil belajarsiswa yang kurang dalam pembelajaran PKn dikarenakan penilaian yangkurang tepat, (c) Merumuskan tindakan untuk perbaikan dengan tepat dan sesuai yaitudengan penilaian portofolio, (d) Menyusun rencana penelitian berupa rangkaian kegiatan disertai siklus tindakannya.

2. Tahap pelaksanaan (action) Meliputi apa yang dilakukan guru atau peneliti sebagai upayaperbaikan, peningkatan, atau perubahan yang diinginkan. Kegiatan dalamtahap pelaksanaan ini yaitu setelah memperoleh gambaran tentangpembelajaran PKn, bagaimana keadaan siswa, bagaimana guru menilai,kondisi kelas, serta sarana pembelajaran maka dilakukan tindakan yaitupenggunaan penilaian portofolio dalam pembelajaran PKn sehingga ketigaaspek kemampuan siswa dapat dinilai dengan obyektif.

3. Tahap observasi (observation) Meliputi kegiatan mengamati atas hasil atau dampak dan proses daritindakan yang dilaksanakan atau dikenakan pada siswa. Tahap ini diperlukan adanya alat atau instrumen penelitian. Kegiatannya yaitu mengamati prosesdan hasil bahwa penilaian portofolio sesuai digunakan dalam pembelajaran PKn sehingga dapat meningkatkan hasil belajar siswa.

4. Tahap refleksi (reflection) Disini peneliti mengkaji, melihat, dan mempertimbangkan atas prosesdan hasil tindakan dari berbagai kriteria. Kegiatannya yaitu melakukan evaluasi untuk mengukur peningkatan hasil belajar siswa melalui berbagaiinstrumen apakah penilaian lebih efektif setelah diterapkan penilaianportofolio.

Instrumen penelitian yang digunakan pada penelitian ini adalah: 1) Lember Observasi, 2) Soal Evaluasi, dan 3) dokumentasi. Lembar observasi yang digunakan dalam penelitian ada dua, yaitu lembar observasi siswa dan lembar observasi guru. Lembar observasi siswaberisi tentang kegiatan siswa dalam proses pembelajaran melalui Model Pembelajaran Berbasis Portofolio. Kegiatan siswa di antaranya yaitu partisipasi siswa, keaktifan, tanggung jawab, kerja sama, serta sikap cinta danproduk Indonesia. Lembar observasi guru berisi tentang komponen yang diselenggarakan oleh guru dalam proses pembelajaran.

Soal evaluasi digunakan sebagai pedoman untuk memperoleh data hasil belajarsiswa. Soal evaluasi yang akan digunakan terlebih dahulu divalidasi oleh ahli materi dalam bidang PKn. Sedangkan dokumentasi dari dokumen-dokumen dalam penelitian ini dapat memberikan gambaran konkret mengenai kondisi siswa pada saat pembelajaran dan untuk memperkuat data yang diperoleh. Dokumendokumen tersebut berupa foto yang memberikan gambaran secara konkret mengenai kondisi kegiatan siswa saat berlangsungnya proses pembelajaran dilaksanakan pada tiap pertemuan.

Kriteria keberhasilan dalam penelitian ini adalah adanya peningkatan hasilbelajar siswa yang meliputi tiga ranah yaitu ranah kognitif (tes dan produk), afektif, dan psikomotorik. Kriteria keberhasilan dari ketiga ranah tersebut untukjelasnya kami sajikan dalam tabel di bawah ini.

Tabel 1. KKM Penelitian

\begin{tabular}{|c|c|c|}
\hline \multirow[b]{2}{*}{ Ranah yang dinilai } & \multicolumn{2}{|c|}{ KKM } \\
\hline & Kuantitatif & Kualitatif \\
\hline Kognitif (tes) & 71 & Tuntas \\
\hline Kognitif (produk) & 71 & Tuntas \\
\hline Afektif & 10 & Baik \\
\hline Psikomotorik & 4 & Baik \\
\hline
\end{tabular}


Proses pembelajaran menggunakan model pembelajaran berbasis portofolio dikatakan berhasil jika $75 \%$ dari jumlah siswa yang mengikuti proses pembelajaran telah mencapai kriteria keberhasilan yang telah ditentukan.

\section{Hasil dan Pembahasan}

Penelitian ini dilakukan di SD No. 3 Pelaga Tahun Pelajaran 2016/2017. peneliatian ini berlangsung selama dua bulan dari bulan Juli sampai bulan Agustus. Padakelas 4 SD No. 3 Pelaga berjumlah 22 orang siswa, yang terdiri dari 16 orang siswa laki-laki dan 6 orang siswa perempuan. Hasil pengamatan yang dilakukan bahwa keaktifan danprestasi belajar siswa kelas 4 SD No. 3 Pelaga Tahun Pelajaran 2016/2017 memang kurang. Hal initerbukti dari rata-rata nilai 63,64 yang didapatkan siswa, diketahui pula bahwaguru dalam bidang pembelajaran belum pernah menggunakan Metode Pembelajaran Berbasis Portofolio dalam kegiatan pembelajaran mata pelajaran PKn.Peneltian tindakan kelas inidirencanakan 2 siklus apabila siswa mampu memenuhi target peneliti dalammencapai hasil yang diharapkan.

Siklus I

a. Perencanaan siklus I

Hipotesis dalam penelitian ini adalah pembelajaran PKn dengan menerapkan Model Pembelajaran Berbasis Portofolio akan dapatmeningkatkan hasil belajar siswa kelas IV SD No. 3 Pelaga. Pelaksanaan siklus I disesuaikan dengan tahapan yang telah direncanakan. Tahap persiapan dimulai dengan menyusun materi yang akan diberikandengan melihat tujuan pembelajaran yang tercantum dalam silabus. Kemudian peneliti menyusun Rencana Pelaksanaan Pembelajaran (RPP) yang akan digunakan sebagai acuan dalam melaksanakan proses belajar mengajar. Penyusunan RPP selalu berada di bawah bimbingan guru kelasIV agar tujuan pembelajaran tetap dapat tercapai secara efektif dan efisien. Tahap selanjutnya peneliti menyiapkan materi yang akan disampaikan selama siklus I sekaligus menjelaskan kepada guru kelasyang nantinya akan diminta sebagai observer, tentang operasional penerapan Model Pembelajaran Berbasis Portofolio pada setiap pertemuan. Pelaksanaan penelitian tindakan kelas pada siklus I dilaksanakan sebanyak empat kali pertemuan. Adapun kompetensi dasar yang akan dicapai siswa pada siklus I ini yaitu "Memberikan contoh sederhana pengaruhg lobalisasi di lingkungannya". Dari kompetensi dasar tersebut, indikator serta tujuan pembelajaran yang ingin dicapai adalah: (1) Memberikan contoh pengaruh positif globalisasi di lingkungannya; (2) Memberikan contoh pengaruh negatif globalisasi di lingkungannya.

b. Pelaksanaan tindakan siklus I

Tindakan siklus I mulai dilaksanakan pada tanggal 23 April. Indikator pembelajaran dalam pertemuan pertama ini adalah memberikan contoh pengaruh positif dan negatif globalisasi dilingkungannya. Pembelajaran diawali dengan apersepsi, gurumenanyakan mengenai alat komunikasi jaman dahulu dan sekarang. Guru meminta 2 siswa untuk melakukan demonstrasi menelpon menggunakan handphone yang dipinjami dari guru. Guru bertanya keuntungan apa saja yang diperoleh dari kegiatan menelpon jika dibandingkan jaman dulu waktu masih menggunakan alat komunikasi berupa surat. Pada kegiatan inti, siswa dibimbing guru untuk mengartikan globalisasi. Untuk memantapkan pengetahuan siswa mengenai pengertian globalisasi, siswa diminta memperhatikan tayangan multimedia yang berisikan pengertian globalisasi.

Beberapa siswa tampak antusias dan bersemangat, tetapi juga ada siswa yang belumkonsentrasi dalam kegiatan pembelajaran. Ada siswa yang memukul-mukul meja, jalan-jalan, berbicara sendiri dan ada yang menanyakan hal di luar materi pelajaran kepada observer (guru kelas IV). Guru dengan sedikit kualahan melanjutkan pembelajaran. Guru menerapkan langkah-langkah Model Pembelajaran Berbasis Portofolio(MPBP).

Langkah pertama yang dilaksanakan pada pertemuan pertamaadalah mengidentifikasi masalah. Langkah ini meliputi pembentukan kelompok kecil dan pemberian PR. Dalam kegiatan mengidentifikasmasalah, siswa ditanya oleh guru, apakah globalisasi memberikan pengaruh terhadap kehidupan manusia. Merujuk dari jawaban siswa,guru menjelaskan bahwa globalisasi memberikan pengaruh positif dannegatif dalam kehidupan manusia. Guru menjelaskan bahwa nanti siswalah yang akan mencari bidang-bidang dalam kehidupan manusia yang terpengaruh oleh globalisasi. Pembelajaran dilanjutkan dengan pembentukan kelompok. Siswadibentuk menjadi 6 kelompok. Satu kelompok beranggotakan 4-5 siswa. Pembentukan kelompok ditentukan oleh guru berdasarkantempat tinggal dan prestasi siswa. Tugas masing-masing kelompoka dalah mencari bidang-bidang kehidupan manusia yang terpengaruh globalisasi.

Siswa diminta memilih media cetak yang akan dipilih sebagai sumber belajar dalam menyelesaikan tugas kelompok. Mediacetak yang ditawarkan guru adalah surat harian, majalah, dan buletin.Siswa mengeluarkan pendapatnya mengenai media cetak yang akandigunakan, dan media 
cetak yang terpilih yaitu surat harian. Pada akhir pembelajaran guru memberikan Pekerjaan Rumah(PR) kepada siswa untuk dikerjakan di rumah. Masing-masing kelompok mendapat PR mencari bidang-bidang kehidupan manusia yang terpengaruh oleh globalisasi. Guru tidak lupa untuk menanamkansikap untuk bisa bekerjasama dengan teman.

c. Tahap Refleksi

Kegiatan terakhir yang dilakukan peneliti adalah melakukan refleksi terhadaptindakan yang telah dilakukan. Pelaksanaan siklus 1 yang dilaksanakan dengan menggunakanmodel Pembelajaran berbasis portofolio menunjukkan bahwa penggunaan metode ini sudah dilaksanakan secara optimal. Initerlihat dari hasil tes siswa yang sudah berhasil mencapai target nilai yang sudah ditentukan oleh peneliti.

Rata-rata kemampuan siswa kelas 4 pada siklus 1 adalah 63,64. Pada siklus 1, indikator keberhasilan penelitian sebesar $50 \%$ belum dapat dicapai. Tingkat kemampuan siswa pada mata pelajaran PKn materi pengaruh positif dan negative globalisasi pada lingkunganberada dalam kategori cukup. Karena masih berada pada rata-rata $63,64 \%$.

Pelaksanaan siklus 1 dihadiri 22 orang siswa. Siswa yang memperoleh nilai 85-100 tidak ada, siswa yang memperoleh nilai 75-84 adalah 13 orang siswa (59,09\%), siswa yang memperoleh nilai 61-74 adalah 9 orang siswa (40,91\%), dan siswa yang memperoleh nilai 51-60 adalah tidak ada, secara keseluruhan kemampuan penguasaan Siswa terhadap Materi pengaruh positif dan negative globalisasi terhadap limgkungan adalah 73,64.

Dari hasil perencanaan tindakan, pelaksanaan tindakan dan observasi, meningkatkan keaktifan dan prestasi belajar siswa dalam matapelajaran PKn kelas 4 SD No. 3 PelagaTahun Pelajaran 2016/2017 diperoleh nilai rata-rata 73,64 katagori (Cukup) maka belumsesuai dengan indicator keberhasilan minimal 75, oleh karena itu pula ditindak lanjuti pada siklus 2.

Siklus II

Pelaksanaan penelitian dalam siklus I dan II menggunakan sumber belajar berupa media cetak dan media elektronik. Siswa dalam kesempatan ini berlatih memadukan antara konsep yang diperoleh dari penjelasan guru dandari berbagai sumber belajar lain. Siswa mendapat kesempatan untukmengakses informasi di luar kelas baik informasi yang sifatnya benda /bacaan, audio-video (TV/ radio/internet). Siswa dilatih untuk membuat suatu keputusan yang berkaitan dengan konsep yang telah dipelajarinya, dengan mempertimbangkan nilai-nilai yang ada di masyarakat.

Pada siklus 2, indikator keberhasilan penelitian sebesar 8,63\% dapat dicapai. Tingkat kemampuan membaca dan memahami isi bacaan siswa telah masuk katagori baik karena telah berada pada angka $82,27$.

Pelaksanaan pada siklus 2 ini dihadiri oleh 22 orang siswa. Jumlah inilah dijadikan subjek penelitian. Siswa yang memperoleh nilai 85 - 100 adalah 11 orang (50.00\%), siswa yang memperoleh nilai 75 - 84 adalah 11 orang (50.00\%), siswa yang memperoleh nilai 61 - 74 adalah tidak ada, siswa yang memperoleh nilai 51 - 60 adalah tidak ada, dan siswa yang gagal juga tidak ada. dengan demikian, dari hasil pelaksanaan tindakan siklus 2 dapat diketahui bahwa secara keseluruhan meningkatkan hasil belajar siswa pada mata pelajaran PKn kelas 4SD No. 3 Pelaga Tahun Pelajaran 2016/2017 nilai rata-rata adalah 82,27.

Dengan demikian hasil pelaksanaan siklus 2 banyak siswa yang mengalami peningkatan. Ini dibuktikan dengan meningkatnya rata-rata nilai siswa dari 73,64 menjadi 82,27 pada siklus 2 . Jadi peningkatan nilai pada siklus 2 sebesar 8,63.

\section{Simpulan Dan Saran}

Berdasarkan analisis data dan pembahasan pada bab IV, maka dapat diambil kesimpulan bahwa penggunaan Model Pembelajaran Berbasis Portofolio dapat meningkatkan kualitas proses pembelajaran. Melalui Model Pembelajaran Berbasis Portofolio, proses pembelajaran dilaksanakan dengan menerapkan prinsip belajar siswa aktif, kelompok belajar kooperatif, pembelajaran partisipatorik, dan reactive teaching, serta dilaksanakan proses pembelajaran yang sesuai dengan landasan pemikiran Model Pembelajaran Berbasis Portofolio, yaitu empat pilar pendidikan (learning to do, learning to know, learnig to be, dan learning to live together), pandangan konstruktif, dan democratic teaching.

Keberhasilan penerapan Model Pembelajaran Berbasis Portofolio sebagaisalah satu upaya untuk meningkatkan hasil belajar siswa dapat dijadikan dasarbagi peneliti untuk memberikan saran-saran sebagai berikut: 1) Siswa ikut berpartisipasi aktif selama proses pembelajaran di kelas, 2) Siswa bekerja sama dengan baik dalam kelompok-kelompok belajarsehingga mengasah keterampilan sosialnya, 3) Siswa terlibat langsung dalam proses pembelajaran sehingga prosesbelajar dialami sendiri, 4) Siswa sebaiknya 
menerapkan nilai-nilai demokrasi yang tertuang dalamproses pembelajaran, sehingga dapat membekali diri untuk menjadiwarga negara yang baik sesuai dengan tujuan umum mata pelajaran PKn, 5) Guru dapat menerapkan Model Pembelajaran Berbasis Portofolio sebagai model pembelajaran alternatif dalam menyampaikan materi matapelajaran PKn untuk siswa kelas IV di SD Negeri Gendengan, 6) Guru sebaiknya merubah gaya belajar agar suasana belajar lebih menyenangkan yaitu dengan mengutamakan peran aktif siswa danmengajak siswa belajar dalam kelompok-kelompok belajar, 7) Guru dalam pelaksanaan proses pembelajaran khususnya pada matapelajaran PKn sebaiknya senantiasa menanamkan nilai-nilai demokrasi, 8) Kepala sekolah diharapkan memberikan dukungan yang positif kepadaguru-guru untuk mengadakan inovasi dalam proses pembelajaran.

\section{Daftar Rujukan}

Anita Lie. 1997. Cooperative Learning. Jakarta : Gramedia Widiasarana Indonesia.

Budimansyah, Dasim. 2002. Model Pembelajaran Ekonomi. Bandung: Genesindo.

Darmayanti, N.P.D., Wiarta, I.W. and Agustika, G.N.S., 2018. Pengaruh Model Pembelajaran STAD berbasis Portofolio terhadap Kompetensi Pengetahuan Matematika. International Journal of Elementary Education, Volume 2, Nomor 3, pp.228-236.

Dewi, D.A.P.H., 2018. Pengaruh Pendekatan Kontextual Teaching and Learning Berbasis Penilaian Portofolio Terhadap Kompetensi Pengetahuan IPA. Journal for Lesson and Learning Studies, Volume 1, Nomor 3.

Fauzia, I.S., Diana, S. and Kusnadi, K., 2018. Pengaruh Pembelajaran Berbasis Proyek dengan Portofolio terhadap Penguasaan Konsep Angiospermae dan Sikap Siswa SMA terhadap Sains. Assimilation: Indonesian Journal of Biology Education, Volume 1, Nomor 2, pp.62-69.

Malian, Sobirin dan Marzuki Suparman. 2003. Pendidikan Kewarganagaraan dan. Hak Asasi Manusia. Yogyakarta: UII Pres.

Ningtyas, D.A., 2018. Pengaruh Penerapan Asesmen Portofolio Proses dalam Model Inkuiri Terbimbing terhadap Keterampilan Berpikir Kritis dan Hasil Belajar Biologi Siswa Kelas X SMA Negeri 2 Batu. Jurnal Pendidikan Biologi, Volume 9, Nomor 1, pp.1-9.

Purwani, N.P.R., Darsana, I.W. and Manuaba, I.B.S., 2018. Pengaruh Model Pembelajaran Picture and Picture Berbasis Portofolio Terhadap Hasil Belajar IPA Siswa. International Journal of Elementary Education, Volume 2, Nomor 3, pp.165-172.

Suhardjono dan Supardi.2007. Penelitian Tindakan kelas. Jakarta: Bumi Aksara.

Sulastri, S., 2018. Upaya Meningkatkan Minat Belajar Siswa melalui Model Pembelajaran Portofolio pada Pelajaran IPS Kelas IV SDN 1 Keteguhan. Lentera: Jurnal Ilmiah Kependidikan, Volume 11, Nomor 2, pp.65-82.

Suyanto. 1996. Pedoman Penelitian Tindakan Kelas. Yogyakarta: UP35D IKIP. Bandung: Angkasa.

Wulandari, P., Abadi, I.B.G.S., SE, M. and Suniasih, N.W., 2018. Pengaruh Model Pembelajaran Think Pair Share berbasis Penilaian Portofolio terhadap Kompetensi Pengetahuan IPA Siswa Kelas IV SD Negeri Gugus Kapten Kompyang Sujana Denpasar Barat Tahun 2017/2018. MIMBAR PGSD Undiksha, Volume 6, Nomor 3.

Wulandari, K.E., Suarni, K. and Renda, N.T., 2018. Pengaruh Model Pembelajaran Make A Match Berbasis Penilaian Portofolio Terhadap Hasil Belajar IPA. Journal of Education Action Research, Volume 2, Nomor 3, pp.240-248. 
Ulum, Z. and Anggraini, D., 2018. Efektivitas Model Pembelajaran Berbasis Portofolio Pada Materi Persamaan Linear Dua Variabel Di Smp Negeri 1 Torjun. APOTEMA: Jurnal Program Studi Pendidikan Matematika, Volume 4, Nomor 1, pp.8-15. 